\title{
Comparison of exogenous glucose, fructose and galactose oxidation during exercise using ${ }^{13} \mathrm{C}$-labelling
}

\author{
Yan Burelle ${ }^{1}$, Marie-Catherine Lamoureux ${ }^{1}$, François Péronnet ${ }^{1}$, Denis Massicotte ${ }^{2 *}$ and Carole Lavoie ${ }^{3}$ \\ ${ }^{1}$ Department of Kinesiology, University of Montreal, CP 6128 Centre Ville, Montreal, Quebec, H3C 3J7, Canada \\ ${ }^{2}$ Department of Kinanthropology, University of Quebec at Montreal, Montreal, Quebec, H3C 3P8, Canada \\ ${ }^{3}$ Department of Science of Physical Activity, University of Quebec at Trois-Rivières, Quebec, G9A 5H7, Canada
}

(Received 27 October 2005 - Revised 21 February 2006 - Accepted 6 March 2006)

\begin{abstract}
Six subjects exercised for 120 min on a cycle ergometer (65 (SE 3) \% $\dot{\mathrm{V}}_{\mathrm{O}_{2 \max }}$ ) when ingesting a placebo or glucose, fructose or galactose (100 g in $1000 \mathrm{ml}$ water) labelled with ${ }^{13} \mathrm{C}$. The oxidation of energy substrates including exogenous hexoses was compared using indirect respiratory calorimetry and ${ }^{13} \mathrm{CO}_{2}$ production at the mouth. Total carbohydrate progressively decreased and total fat oxidation increased over the 120 min exercise period in the four experimental situations. During the $120 \mathrm{~min}$ of exercise, the amount of fructose oxidized (38.8 (SE 2.6) g; 9.0 (SE 0.6) \% energy yield) was not significantly (approximately $4 \%$ ) lower than that of exogenous glucose (40.5 (SE 3.4) g; 9.2 (SE 0.8) \% energy yield), while that of galactose (23.7 (SE 3.5) g; 5.5 (SE 0.9) \% energy yield) was only $59 \%$ and $61 \%$ that of glucose and fructose, respectively. When compared with the placebo, the ingestion and oxidation of the three hexoses did not significantly modify fat oxidation or total carbohydrate oxidation, but it significantly reduced $(9-13 \%)$ endogenous carbohydrate oxidation. The present data indicate that fructose and exogenous glucose ingested during exercise could be oxidized at a similar rate, but that the oxidation rate of galactose was only approximately $60 \%$ that of the exogenous glucose and fructose, presumably because of a preferential incorporation of galactose into liver glycogen (Leloir pathway). The reduction in endogenous carbohydrate oxidation was, however, similar with the three hexoses.
\end{abstract}

Stable isotope: Exogenous hexoses: Calorimetry

When they are ingested in large amounts ( $1.8-2 \cdot 4 \mathrm{~g} / \mathrm{min})$ during prolonged moderate exercise, the oxidation of exogenous glucose or glucose polymers could exceed $1 \mathrm{~g} / \mathrm{min}$ and could provide up to $30-40 \%$ of the energy yield (Couture et al. 2002; Jentjens et al. 2004a,b; Wallis et al. 2005). When compared with that of exogenous glucose or starch, the oxidation of fructose has been shown to be $15 \%$ higher (Décombaz et al. 1985), similar (Slama et al. 1989; Burelle et al. 1997) or approximately 20-25\% lower (Massicotte et al. 1986, 1989, 1990, 1994; Guézennec et al. 1989; Jandrain et al. 1993; Adopo et al. 1994), and both hexoses have been shown to reduce endogenous carbohydrate (CHO) oxidation (Massicotte et al. 1986, 1989, 1990, 1994; Wagenmakers et al. 1993; Jeukendrup et al. 1999; Couture et al. 2002; Jentjens et al. 2004a,b). As for galactose, Stellaard et al. (2000) have observed at rest a $35 \%$ lower recovery of ${ }^{13} \mathrm{CO}_{2}$ following the ingestion of galactose compared with glucose $(40 \mathrm{~g})$. In the only study available during exercise, the oxidation rate of galactose was approximately $48 \%$ that of exogenous glucose (Leijssen et al. 1995), but no control situation (i.e. exercise with ingestion of water) was included to ascertain the effect of galactose ingestion and oxidation on endogenous substrate utilization.

The purpose of the present study was to further compare the oxidation rate of glucose, fructose and galactose, and the associated changes in endogenous substrate oxidation, during prolonged exercise. Based on data from various studies concerning fructose oxidation (Décombaz et al. 1985; Massicotte et al. 1986, 1989, 1990, 1994; Guézennec et al. 1989; Jandrain et al. 1993; Burelle et al. 1997; Adopo et al. 1994), and from the studies by Leijssen et al. (1995) and Stellaard et al. (2000) concerning the oxidation of galactose, we hypothesized that the oxidation rate of fructose would be similar to or slightly lower than that of exogenous glucose, whereas that of galactose would be only about half that exogenous glucose. We also hypothesized that the reduction in endogenous $\mathrm{CHO}$ oxidation would be lower with galactose than with glucose or fructose.

\begin{abstract}
Methods
Subjects

The experiments were conducted on six active healthy male subjects who gave their informed written consent to participate in the study, which was approved by the Institutional Board on the Use of Human Subjects in Research. Their mean age, body mass, height, fasting plasma glucose concentration and maximal oxygen uptake on a cycle ergometer were
\end{abstract}


21 (SE 1) years, 65 (SE 2) kg, 172 (SE 2) cm, 4.76 (SE 0.21) $\mathrm{mmol} / \mathrm{l}$ and 4.40 (SE 0.06) $1 / \mathrm{min}$, respectively.

\section{Experimental protocol}

The $\dot{\mathrm{V}}_{\mathrm{O}_{2 \max }}$ and experimental workloads on a cycle ergometer (Ergomeca, La Bayette, France) were determined for each subject during a preliminary test session using open-circuit spirometry (1100 Medical Gas Analyser; Marquette Electronics, Milwaukee, Wisconsin, USA). Subsequently, at 1-week intervals beginning at 13.00 hours, all subjects performed four exercise sessions of $120 \mathrm{~min}$ duration at a workload corresponding to $65 \quad(\mathrm{SE} \quad 3) \% \quad \dot{\mathrm{V}}_{\mathrm{O}_{2 \max }} \quad(218.3$ (SE 10.6) W). The last evening meal (19.00 hours: $5450 \mathrm{~kJ}$, approximate values $55 \% \mathrm{CHO}, 30 \%$ fat, $15 \%$ protein), the morning breakfast $(07.30$ hours: $3350 \mathrm{~kJ}$, approximate values $60 \% \mathrm{CHO}, 30 \%$ fat, $10 \%$ protein) and a small snack ingested $2 \mathrm{~h}$ before the beginning of exercise $(11.00$ hours: $2100 \mathrm{~kJ}$, approximate values $50 \% \mathrm{CHO}, 35 \%$ fat, $15 \%$ protein) were standardized.

In addition, in order to keep a low background ${ }^{13} \mathrm{C}$ enrichment of expired $\mathrm{CO}_{2}$, the ingestion of $\mathrm{CHO}$ from plants with a $\mathrm{C}_{4}$ photosynthetic cycle, which are naturally enriched in ${ }^{13} \mathrm{C}$ (Lefèbvre, 1985), was avoided during the period of experiments. Subjects also refrained from exercising, and from drinking coffee and alcohol for $2 \mathrm{~d}$ before each experiment.

During the exercise period, the subjects ingested $1000 \mathrm{ml}$ water at room temperature with a low-calorie sweetener (Aspartam; Nabisco, Etobicoke, Ontario, Canada) as a placebo, or $100 \mathrm{~g}$ glucose, fructose or galactose in $1000 \mathrm{ml}$ water. The solutions were given in five $200 \mathrm{ml}$ doses taken immediately before the beginning of exercise and at 20,40, 60 and $80 \mathrm{~min}$ during the exercise period. The hexoses ingested were artificially labelled with ${ }^{13} \mathrm{C}$. Glucose, fructose (Biopharm, Laval, Quebec, Canada; -11.03 and $-10.91 \% o \delta{ }^{13} \mathrm{C}$ Pee Dee Bilemnitella (PDB-1), respectively) and galactose (Sigma Chemicals, St Louis, MO, USA; - 23.4\% $\delta{ }^{13} \mathrm{C}$ PDB-1) were respectively enriched with $\left[\mathrm{U}^{13} \mathrm{C}_{6}\right]$-glucose, $\left[\mathrm{U}^{13} \mathrm{C}_{6}\right]$-fructose and $\left[1{ }^{13} \mathrm{C}_{1}\right]$ galactose (ICN Pharmaceuticals Inc, Costa Mesa, CA, USA) in order to achieve final isotopic compositions close to $+25 \%$ o $\delta$ ${ }^{13} \mathrm{C}$ PDB-1 (actual values measured by mass spectrometry $+24 \cdot 5,+24 \cdot 1$ and $+24 \cdot 2 \% \circ \delta{ }^{13} \mathrm{C}$ PDB-1, for glucose, fructose and galactose, respectively).

\section{Measures and calculations}

Observations were made at rest immediately before exercise and every $30 \mathrm{~min}$ during the exercise period. Fat and $\mathrm{CHO}$ oxidation were computed from oxygen consumption $\left(\dot{\mathrm{V}}_{\mathrm{O}_{2}}\right)$ and carbon dioxide production $\left(\dot{\mathrm{V}}_{\mathrm{CO}_{2}}\right)$ using open-circuit spirometry (10 min collection periods). For the measurement of ${ }^{13} \mathrm{C}:{ }^{12} \mathrm{C}$ in expired $\mathrm{CO}_{2}, 80 \mathrm{ml}$ samples of expired gas were collected and stored in Vacutainers (Becton Dickinson, Franklin Lakes, NJ, USA). Finally, $8 \mathrm{ml}$ blood samples were withdrawn through a catheter (Baxter Health Care Corp. Valencia, CA, USA) inserted into an antecubital vein $30 \mathrm{~min}$ before the beginning of experiment, for the measurement of plasma glucose (Sigma Diagnostics, Sigma, Mississauga, Ontario, Canada) and insulin (KTSP-11001; Immunocorp Sciences, Montreal, Quebec, Canada) concentrations. Plasma samples were stored at $-80{ }^{\circ} \mathrm{C}$ until analysis.
Measurements of ${ }^{13} \mathrm{C}:{ }^{12} \mathrm{C}$ in expired $\mathrm{CO}_{2}$ and in $\mathrm{CO}_{2}$ from the combustion of ingested glucose, fructose and galactose were performed by mass spectrometry (Prism; VG, Manchester, UK) following cryodistillation as previously described (Adopo et al. 1994). The isotopic composition was expressed in \%o difference by comparison with the PDB-1 Chicago Standard: $\% o \delta{ }^{13} \mathrm{C}$ PDB- $1=\left(\left(\mathrm{R}_{\mathrm{spl}} / \mathrm{R}_{\mathrm{std}}\right)-1\right) \times 1000$, where $\mathrm{R}_{\mathrm{spl}}$ and $\mathrm{R}_{\text {std }}$ are the ${ }^{13} \mathrm{C}:{ }^{12} \mathrm{C}$ ratio in the sample and standard $(1.1237 \%)$, respectively (Craig, 1953).

The oxidation of $\mathrm{CHO}$ (expressed in $\mathrm{g}$ glucose/min) and fat were calculated from $\dot{\mathrm{V}}_{\mathrm{O}_{2}}$ and $\dot{\mathrm{V}}_{\mathrm{CO}_{2}}$ as follows (Péronnet \& Massicotte, 1991):

$$
\begin{gathered}
\mathrm{CHO}=4.59 \dot{\mathrm{V}}_{\mathrm{CO}_{2}}-3.23 \dot{\mathrm{V}}_{\mathrm{O}_{2}} \\
\text { Fat }=1.69\left(\dot{\mathrm{V}}_{\mathrm{O}_{2}}-\dot{\mathrm{V}}_{\mathrm{CO}_{2}}\right)
\end{gathered}
$$

with mass in $\mathrm{g}$ and gas volume in LSTPD. The oxidation rate of the exogenous hexose $\left(m_{\text {exo }} ; \mathrm{g} / \mathrm{min}\right)$ was calculated as follows:

$$
m_{\text {exo }}=\dot{\mathrm{V}}_{\mathrm{CO}_{2}}\left[\left(R_{\text {exp }}-R_{\text {ref }}\right) /\left(R_{\text {exo }}-R_{\text {ref }}\right)\right] / k
$$

where $\dot{\mathrm{V}}_{\mathrm{CO}_{2}}$ is in $\mathrm{L}_{\mathrm{STPD}} / \mathrm{min}, R_{\exp }$ is the ${ }^{13} \mathrm{C}:{ }^{12} \mathrm{C}$ observed in expired $\mathrm{CO}_{2}, R_{\text {ref }}$ is the ${ }^{13} \mathrm{C}:{ }^{12} \mathrm{C}$ in expired $\mathrm{CO}_{2}$ in the control trial, $R_{\text {exo }}$ is the ${ }^{13} \mathrm{C}:{ }^{12} \mathrm{C}$ in the exogenous glucose, fructose or galactose ingested, and $k(0.747 \mathrm{l} / \mathrm{g})$ is the volume of $\mathrm{CO}_{2}$ provided by the complete oxidation of glucose, fructose or galactose. Endogenous $\mathrm{CHO}$ oxidation (g glucose/min) was calculated by the difference between total $\mathrm{CHO}$ and exogenous hexose oxidation. The contribution of the oxidation of the various substrates to the energy yield was computed from their respective energy potential.

These calculations are made based on the observation that, in response to exercise, ${ }^{13} \mathrm{C}$ is not irreversibly lost in pools of tricarboxylic acid cycle intermediates (Ruzzin et al. 2003) and/or bicarbonate (Trimmer et al. 2001), and that ${ }^{13} \mathrm{CO}_{2}$ recovery in expired gases is thus complete or almost complete. In addition, because ${ }^{13} \mathrm{C}:{ }^{12} \mathrm{C}$ in expired $\mathrm{CO}_{2}$ equilibrates only slowly with ${ }^{13} \mathrm{C}:{ }^{12} \mathrm{C}$ in the $\mathrm{CO}_{2}$ produced in the tissues (Pallikarakis et al. 1991), the absolute value for exogenous hexose oxidation could be somewhat underestimated at the beginning of exercise. This phenomenon probably does not, however, compromise the comparison of the availability of the three hexoses for oxidation.

\section{Statistics}

Data are presented as means with their standard errors. The main effects of time and exogenous substrate ingested, as well as time-substrate interactions, were tested by repeatedmeasures ANOVA (Statistica package; StatSoft, Tulsa, OK, USA). Newman-Keuls post hoc tests were used to identify the location of significant differences $(P<0 \cdot 05)$ when ANOVA yielded a significant $F$ ratio.

\section{Results}

Over the 120 min of exercise, $\dot{\mathrm{V}}_{\mathrm{O}_{2}}$, which was stable, and RER, which significantly decreased, were not significantly different in the four experimental situations (Table 1). At rest before ingestion of the placebo or the ${ }^{13} \mathrm{C}$-hexose, the ${ }^{13} \mathrm{C}:{ }^{12} \mathrm{C}$ in expired $\mathrm{CO}_{2}$ was not significantly different in the 
Table 1. Oxygen consumption and respiratory exchange ratio (RER) during the exercise period

\begin{tabular}{|c|c|c|c|c|}
\hline & \multicolumn{2}{|c|}{$0-60 \mathrm{~min}$} & \multicolumn{2}{|c|}{$60-120 \mathrm{~min}$} \\
\hline & Mean & SE & Mean & SE \\
\hline \multicolumn{5}{|l|}{ Placebo } \\
\hline$\dot{\mathrm{V}}_{\mathrm{O}_{2}}(\mathrm{l} / \mathrm{min})$ & $2 \cdot 886$ & 0.083 & $2 \cdot 856$ & 0.065 \\
\hline RER & 0.916 & 0.007 & 0.887 & 0.007 \\
\hline \multicolumn{5}{|l|}{ Glucose } \\
\hline$\dot{\mathrm{V}}_{\mathrm{O}_{2}}(\mathrm{l} / \mathrm{min})$ & $2 \cdot 890$ & 0.126 & $2 \cdot 845$ & 0.101 \\
\hline RER & 0.916 & 0.012 & 0.892 & 0.010 \\
\hline \multicolumn{5}{|l|}{ Fructose } \\
\hline$\dot{\mathrm{V}}_{\mathrm{O}_{2}}(1 / \mathrm{min})$ & $2 \cdot 717$ & 0.103 & $2 \cdot 764$ & 0.068 \\
\hline RER & 0.927 & 0.006 & 0.908 & 0.008 \\
\hline \multicolumn{5}{|l|}{ Galactose } \\
\hline$\dot{\mathrm{V}}_{\mathrm{O}_{2}}(\mathrm{l} / \mathrm{min})$ & 2.796 & 0.109 & 2.803 & 0.088 \\
\hline RER & 0.909 & 0.012 & 0.880 & 0.013 \\
\hline
\end{tabular}

four experimental situations and averaged -22.99 (SE 0.03; pooled data, $n$ 24) (Fig. 1). In response to exercise with ingestion of the placebo, ${ }^{13} \mathrm{C}:{ }^{12} \mathrm{C}$ in expired $\mathrm{CO}_{2}$ increased slightly, as commonly observed (Burelle et al. 2001), and reached a plateau after $30 \mathrm{~min}$ exercise. The increase in ${ }^{13} \mathrm{C}:{ }^{12} \mathrm{C}$ was much higher when ${ }^{13} \mathrm{C}$-enriched hexoses were ingested, but the values observed were significantly higher beginning at 60 min with the ingestion of glucose and fructose than with the ingestion of galactose (main effect).

Substrate oxidation over the exercise period is presented in Table 2. Total $\mathrm{CHO}$ and fat oxidation decreased and increased, respectively, from the first to the second hour of exercise in the four experimental situations but was not significantly different with the placebo and the ingestion of the three hexoses. The amounts of exogenous hexoses oxidized significantly increased

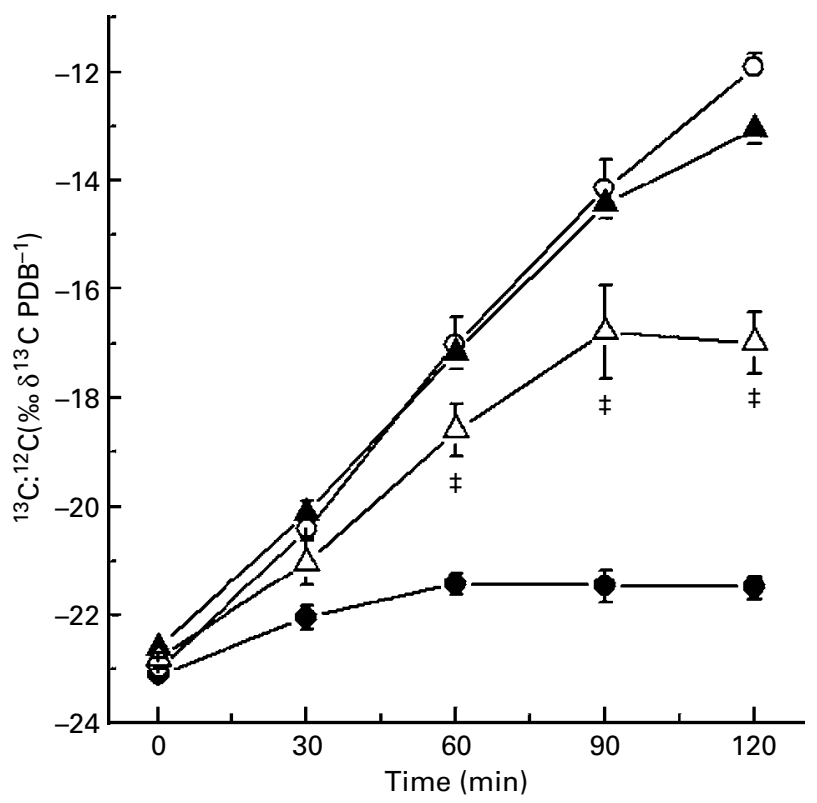

Fig. 1. Changes in ${ }^{13} \mathrm{C}:{ }^{12} \mathrm{C}$ in expired $\mathrm{CO}_{2}$ in response to exercise with ingestion of placebo and ${ }^{13} \mathrm{C}$-labelled hexoses (means and their standard errors; $n 6$ ). $¥$ Values were significantly different from those for glucose and fructose $(P<0.05)$. - - , Placebo; $-\bigcirc-$, glucose; $-\Delta-$, fructose; $-\Delta-$, galactose.
Table 2. Substrate oxidation (g) during the exercise period (Means and their standard errors, $n 6$ )

\begin{tabular}{|c|c|c|c|c|}
\hline & \multicolumn{2}{|c|}{$0-60 \mathrm{~min}$} & \multicolumn{2}{|c|}{$60-120 \mathrm{~min}$} \\
\hline & Mean & SE & Mean & SE \\
\hline \multicolumn{5}{|l|}{ Placebo } \\
\hline $\mathrm{CHO}$ total & $168 \cdot 6$ & $6 \cdot 0$ & $144 \cdot 2^{*}$ & $5 \cdot 1$ \\
\hline Exogenous hexose & 0 & 0 & 0 & 0 \\
\hline Endogenous $\mathrm{CHO}$ & $168 \cdot 6$ & $6 \cdot 0$ & $144 \cdot 2^{*}$ & $5 \cdot 1$ \\
\hline Fat & $23 \cdot 1$ & $2 \cdot 4$ & $31 \cdot 2^{\star}$ & $2 \cdot 3$ \\
\hline \multicolumn{5}{|l|}{ Glucose } \\
\hline $\mathrm{CHO}$ total & $164 \cdot 1$ & $10 \cdot 2$ & $147 \cdot 2^{*}$ & $10 \cdot 0$ \\
\hline Exogenous hexose & $9 \cdot 0$ & 1.4 & $31.5^{\star}$ & $2 \cdot 2$ \\
\hline Endogenous $\mathrm{CHO}$ & $155 \cdot 1$ & $10 \cdot 4$ & $115 \cdot 8^{*} \dagger$ & $10 \cdot 8$ \\
\hline Fat & $22 \cdot 7$ & 3.9 & $29 \cdot 7^{\star}$ & $3 \cdot 3$ \\
\hline \multicolumn{5}{|l|}{ Fructose } \\
\hline $\mathrm{CHO}$ total & $167 \cdot 1$ & $6 \cdot 2$ & $55 \cdot 2^{*}$ & $6 \cdot 4$ \\
\hline Exogenous hexose & 9.2 & $1 \cdot 2$ & $29 \cdot 6^{\star}$ & 1.5 \\
\hline Endogenous $\mathrm{CHO}$ & $158 \cdot 0$ & $6 \cdot 1$ & $125 \cdot 6^{*} \dagger$ & $6 \cdot 3$ \\
\hline Fat & $18 \cdot 6$ & $2 \cdot 1$ & $24 \cdot 4^{*}$ & $2 \cdot 4$ \\
\hline \multicolumn{5}{|l|}{ Galactose } \\
\hline $\mathrm{CHO}$ total & $157 \cdot 3$ & $7 \cdot 6$ & $135 \cdot 0^{*}$ & 7.9 \\
\hline Exogenous hexose & $5 \cdot 6$ & $1 \cdot 1$ & $18 \cdot 1^{\star} \dagger \ddagger$ & $2 \cdot 3$ \\
\hline Endogenous $\mathrm{CHO}$ & $151 \cdot 6$ & $7 \cdot 3$ & $116 \cdot 9^{*} \dagger$ & 5.9 \\
\hline Fat & $24 \cdot 6$ & $4 \cdot 2$ & $33.0^{*}$ & $4 \cdot 7$ \\
\hline
\end{tabular}

$\mathrm{CHO}$, carbohydrate.

*Values were significantly different from the $0-60 \mathrm{~min}$ period $(P<0.05)$.

$\dagger$ Values were significantly different from those for the placebo $(P<0.05)$.

$\ddagger$ Values were significantly different from those for glucose and fructose $(P<0.05)$.

from the first to the second hour of exercise, with no significant difference between exogenous glucose and fructose oxidation. In contrast, the amount of exogenous galactose oxidized was significantly lower (approximately $60 \%$ ) than that of exogenous glucose and fructose over both the first and second hour of exercise. As a consequence, galactose oxidation only contributed $5 \cdot 5$ (SE 0.9$) \%$ to the energy yield (significantly lower than the percentage energy yield from the oxidation of exogenous glucose and fructose: 9.2 (SE 0.8) and 9.0 (SE 0.6) \%, not significantly different). The oxidation of endogenous glucose, which significantly decreased from the first to the second hour of exercise, was significantly lower when exogenous hexoses rather than placebo were ingested. The amount of fat was not significantly modified by ingestion and oxidation of the three hexoses, and was not significantly different, respectively, in the four experimental situations (Fig. 2).

No significant differences were observed between trials for basal plasma glucose and insulin concentration (Fig. 3). Throughout the exercise period, plasma glucose concentration remained at or slightly above basal values (approximately $5.5 \mathrm{mmol} / \mathrm{l}$ ) when glucose or fructose was ingested. Although this did not reach significance, plasma glucose concentration steadily decreased when placebo or galactose was ingested, and the values observed were significantly lower than with glucose or fructose ingestion at $80 \mathrm{~min}$. The plasma insulin concentration significantly decreased in response to exercise but was not significantly different between the four situations (main effect).

\section{Discussion}

The results from the present experiment show that, compared with glucose and for similar amounts ingested during exercise, 


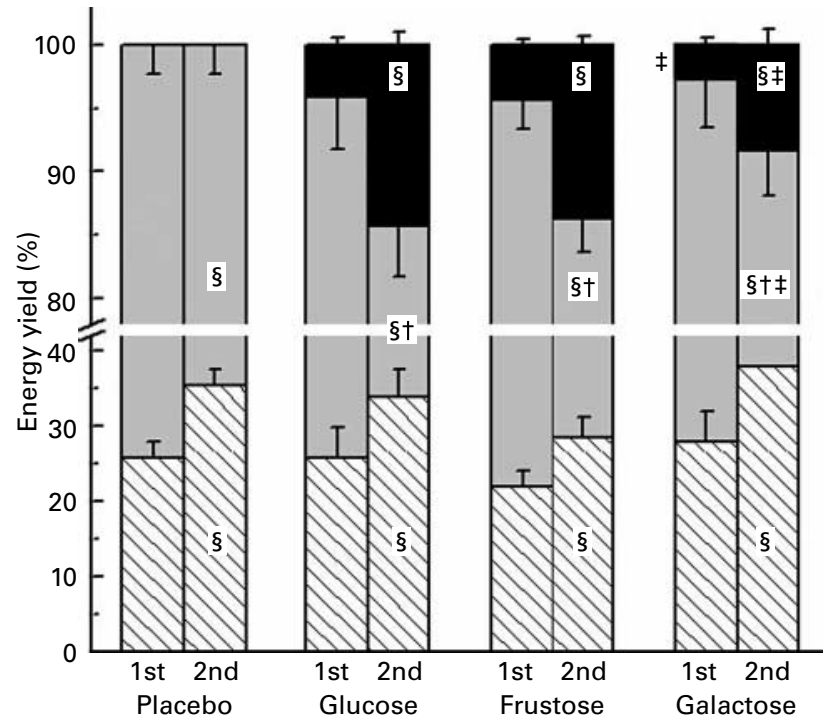

Fig. 2. Percentage contribution to the energy yield of fat $(\mathbb{\nabla})$, endogenous $\mathrm{CHO}(\square)$ and exogenous hexoses ( $\square$ ) over the first and second hours of exercise (mean and their standard errors; $n 6$ ). †Values were significantly different from those for the placebo $(P<0.05)$. $¥$ Values were significantly different from those for glucose and fructose $(P<0.05)$. $\$ Values were significantly different from the first hour $(P<0.05)$.

the oxidation of galactose was significantly lower (approximately $40 \%$ ), whereas the oxidation of fructose was only about $4 \%$ lower and not significantly different. The ingestion of hexoses did not significantly modify total $\mathrm{CHO}$ and fat oxidation, but it significantly reduced (by $9-13 \%$ ) endogenous $\mathrm{CHO}$ oxidation over the $120 \mathrm{~min}$ exercise.

Only one study is available concerning the oxidation of ingested galactose during prolonged exercise (Leijssen et al. 1995). In this study, the oxidation rates of $155 \mathrm{~g}$ exogenous glucose and galactose were compared during 120 min exercise at $65 \% \dot{\mathrm{V}}_{\mathrm{O}_{2 \max }}(3.52 \mathrm{l} / \mathrm{min})$. The amount of galactose oxidized over the exercise period ( $33.4 \mathrm{~g}$ ) was $46 \%$ that of exogenous glucose $(71.7 \mathrm{~g})$. Results from the present experiment are in line with these findings as the amount of galactose oxidized over the $120 \mathrm{~min}$ exercise was 23.7 (SE 3.5) g, a value that was $59 \%$ that of exogenous glucose $(40.5$ v. $3.4 \mathrm{~g})$.

In the study by Leijssen et al. (1995), when compared with glucose ingestion, the lower oxidation rate of galactose was associated with a compensatory $11 \%$ increase in endogenous $\mathrm{CHO}$ oxidation, whereas fat oxidation was similar. However, no control situation with an ingestion of water only was included. In the present study, when compared with the control situation during the $120 \mathrm{~min}$ exercise period, the oxidation of galactose significantly reduced endogenous $\mathrm{CHO}$ oxidation by $14 \%$ but did not modify fat or total $\mathrm{CHO}$ oxidation. When compared with the effect of glucose ingestion, the reduction in endogenous $\mathrm{CHO}$ oxidation was very similar with the ingestion of galactose.

The slightly lower oxidation rate of both exogenous glucose and galactose reported in the present experiment when compared with that reported by Leijssen et al. (1995), as well as the difference in endogenous glucose oxidation, was probably due to the fact that the amounts of exogenous hexose ingested and the absolute workload were both lower (100 v. $155 \mathrm{~g}, 2.82$ v. $3 \cdot 52 \mathrm{l} / \mathrm{min}$, respectively). Indeed, exogenous $\mathrm{CHO}$ oxidation
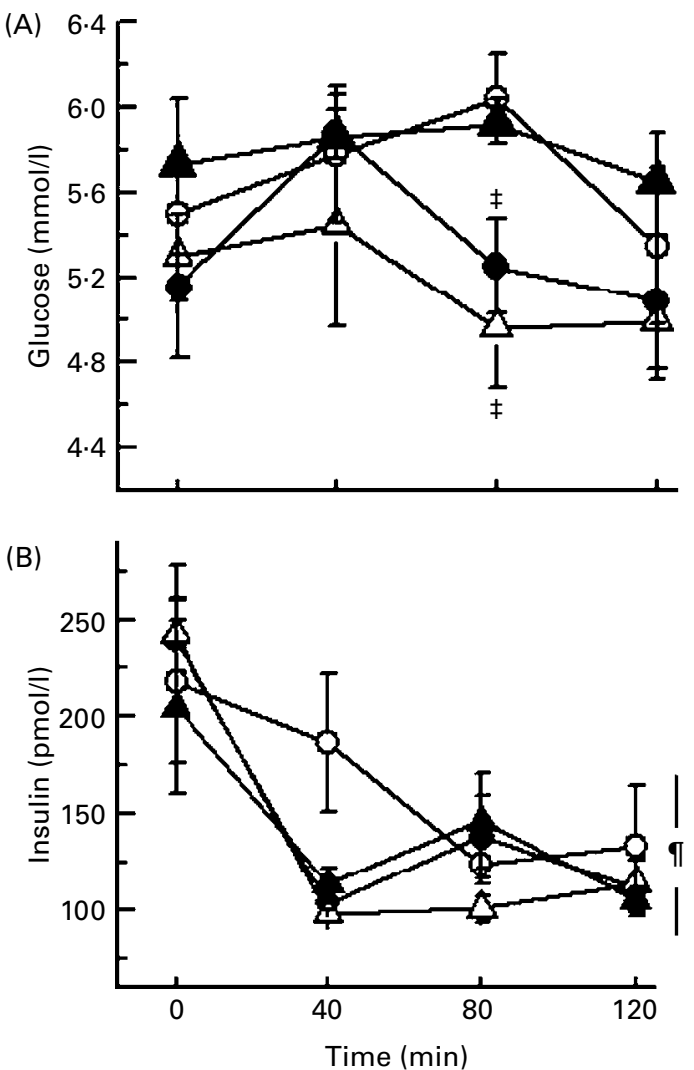

Fig. 3. Plasma concentration of glucose $(A)$ and insulin $(B)$ in the four experimental conditions (mean and their standard errors; $n 6$ ). $\ddagger$ Values were significantly different from those for glucose and fructose $(P<0.05)$. IValues were significantly different from the corresponding value at $0 \mathrm{~min}(P<0.05)$. - - -, Placebo; - - , glucose; $-\boldsymbol{\Lambda}-$, fructose; $-\Delta-$, galactose.

has been shown to increase with workload (Wagenmakers et al. 1993; Massicotte et al. 1994; Pirnay et al. 1995), as well as with amount ingested (Adopo et al. 1994; Jeukendrup et al. 1999; see also Jeukendrup, 2004, for a review).

With exogenous fructose, most studies (Massicotte et al. 1986, 1989, 1990, 1994; Guézennec et al. 1989; Jandrain et al. 1993; Adopo et al. 1994; Burelle et al. 1997) have shown that, for similar amounts ingested, its oxidation rate during prolonged moderate exercise is lower than that of exogenous glucose or starch. In some of these studies, the difference was large (oxidation rate 64-85\% that of exogenous glucose) and statistically significant (Massicotte et al. 1986, 1989, 1990, 1994; Guézennec et al. 1989; Jandrain et al. 1993; Adopo et al. 1994). In contrast, in the studies by Burelle et al. (1997) and by Slama et al. (1989), the difference was smaller (approximately 5-10\%) and not significantly different, and Décombaz et al. (1985) reported a significantly $13 \%$ higher oxidation rate of exogenous fructose than glucose.

In the present experiment, the amount of exogenous fructose oxidized over the $120 \mathrm{~min}$ of exercise period was only approximately $4 \%$ lower than that of exogenous glucose, and the difference was not statistically significant. This observation confirms the fact that, in certain situations, fructose oxidation could be similar to exogenous glucose oxidation. On the basis of the limited experimental data available, however, it is difficult to identify the factor(s) explaining how, in certain 
situations, fructose oxidation could be lower than, similar to or even higher than that of exogenous glucose. Finally, in the present experiment, in line with several studies comparing the effect of glucose and fructose ingestion (Massicotte et al. 1986, 1990, 1994; Jandrain et al. 1993; Adopo et al. 1994), the reduction in endogenous $\mathrm{CHO}$ oxidation observed with fructose was very similar to that observed with ingestion of glucose $(12-17 \%)$.

When compared with that of exogenous glucose, the lower oxidation rate of exogenous galactose and fructose, when present, could be due to difference in intestinal absorption, changes in plasma concentration and renal handling, and in metabolism of the three hexoses in the liver and peripheral tissues (mainly muscle during exercise).

No data are currently available for directly comparing the intestinal absorption of glucose, fructose and galactose at rest or exercise in man, and the mechanisms by which each of these three hexoses is absorbed are not fully understood (Kellett, 2001; Santer et al. 2003; Wright et al. 2003). Glucose, fructose and galactose cross the brush-border membrane of the enterocytes through an active transport mechanism (SGLT1 co-transporter, with a similar affinity for gluctose and galactose but none for fructose; see Wright et al. 2003 for a review) or facilitated diffusion (GLUT2 transporters, which have a higher affinity for glucose but can handle all three hexoses (Kellet, 2001; Wright et al. 2003); GLUT5 transporters, which are highly specific for fructose) (Ferraris \& Diamond, 1997). As for absorption across the basolateral membrane of the enterocyte, the three hexoses appear to share the common facilitated diffusion mediated by GLUT2 transporters (Wright et al. 2003). Glucose could also be absorbed following the formation of glucose-6-phosphate, transport within the endoplasmic reticulum, vesicle trafficking and the release of free glucose outside the cell (Stümpel et al. 2001; Santer et al. 2003).

Taken together, these data suggest that the intestinal absorption of glucose could be slightly more efficient than that of galactose, which in turn could be more efficient than that of fructose. These differences in the intestinal absorption of hexoses could at least partly explain why, in most studies (Massicotte et al. 1986, 1989, 1990, 1994; Guézennec et al. 1989; Slama et al. 1989; Jandrain et al. 1993; Adopo et al. 1994; Burelle et al. 1997), the oxidation rate of exogenous fructose has been shown to be slightly lower (albeit not always statistically significantly lower) than that of exogenous glucose. This does not, however, explain why the oxidation rate of exogenous galactose in response to exercise is much lower than that of exogenous glucose, as shown by Leijssen et al. (1995) as well as in the present experiment.

One possible explanation for the much lower oxidation rate of galactose than fructose or glucose is the loss of galactose in the urine. In contrast to what is observed following the ingestion of glucose (Jeukendrup et al. 1999; Couture et al. 2002; Jentjens et al. 2004a,b) or fructose (Jandrain et al. 1993; Burelle et al. 1997), the ingestion of galactose results in a marked increase in plasma galactose concentration (e.g. $12 \mathrm{mmol} / \mathrm{l}$ at the end of exercise with an ingestion of $155 \mathrm{~g}$ galactose; Leijssen et al. 1995). Because the renal threshold for galactose could be as low as $0.5 \mathrm{mmol} / \mathrm{l}$ (Williams, 1986), this explains why Ganda et al. (1979) recovered from the urine approximately $16 \%$ of a
$32.5 \mathrm{~g}$ dose of galactose ingested at rest (plasma galactose concentration $19 \mathrm{mmol} / \mathrm{l}$ ). Although this was not measured by Leijssen et al. (1995) or in the present study, losses of galactose in the urine could be suspected owing to the large amounts ingested.

Finally, as discussed by Leijssen et al. (1995) for galactose, and as shown for fructose (Jandrain et al. 1993), the lower oxidation rate of these hexoses compared with glucose during prolonged exercise is probably mainly due to their different metabolic fate in the liver and peripheral tissues. Because of the much higher affinity of muscle hexokinase than liver glucokinase for glucose, and because of the stimulation of muscle glucose uptake in response to exercise (for a review, see Pereira \& Lancha, 2004), the oxidation rate of plasma glucose increases markedly, and the oxidation rate of exogenous glucose can reach about $1.2 \mathrm{~g} / \mathrm{min}$ in as much as the ingestion rate is large enough (Jeukendrup et al. 1999; Couture et al. 2002; Jentjens et al. 2004a,b).

In contrast, because of the presence of a fructokinase and a galactokinase, fructose and galactose could be preferentially taken up by the liver (Chen \& Whistler, 1977; Williams, 1986). Data from Ahlborg \& Björkman (1990) indicate that only small amounts of fructose if any are taken up by the muscle, except when the plasma fructose concentration is very high $(8.8 \mathrm{mmol} / \mathrm{l}$ in their study). Data from Jandrain et al. (1993) indicate that exogenous ${ }^{13} \mathrm{C}$-fructose ingested during exercise, and presumably taken up by the liver, was quickly converted into ${ }^{13} \mathrm{C}$-glucose, which was released in the blood and became available for oxidation in the muscle. The same phenomenon has been shown following ${ }^{13} \mathrm{C}$-galactose ingestion at rest (Berry et al. 1995), but no data are currently available on possible conversion of exogenous galactose to plasma glucose during exercise.

Because of the presence of the Leloir pathway (Williams, 1986), galactose could be preferentially converted into liver glycogen, thus escaping oxidation. A preferential incorporation of exogenous galactose into liver glycogen during exercise is suggested by data from Leijssen et al. (1995). In their study, following a $60 \mathrm{~min}$ recovery period after the first $120 \mathrm{~min}$ period of exercise, the oxidation rates of ${ }^{13} \mathrm{C}$-galactose and ${ }^{13} \mathrm{C}$-glucose were similar during a subsequent $30 \mathrm{~min}$ period at $60 \%$ maximal workload. This could reflect the release and oxidation of glucose from liver glycogen synthesized from ${ }^{13} \mathrm{C}$-galactose during the first exercise period and the subsequent recovery.

\section{Acknowledgements}

This work was supported by grants from the Natural Sciences and Engineering Research Council of Canada, and from the Centre de Recherche en Géochimie Isotopique et Géodynamique (UQAM-McGill).

\section{References}

Adopo E, Péronnet F, Massicotte D, Brisson GR \& Hillaire-Marcel C (1994) Respective oxidation of exogenous glucose and fructose given in the same drink during exercise. J Appl Physiol 76, 1014-1019. 
Ahlborg G \& Björkman O (1990) Splanchnic and muscle fructose metabolism during and after exercise. J Appl Physiol 69, $1244-1251$.

Berry GT, Nissim I, Mazur AT, Elsas LJ, Singh RH, Klein PD, Gibson JB, Lin Z \& Segal S (1995) In vivo oxidation of $\left[{ }^{13} \mathrm{C}\right]$ galactose in patients with galactose-1-phosphate uridyltransferase deficiency. Biochem Mol Med 56, 158-165.

Burelle Y, Massicotte D, Lussier M, Lavoie C, Hillaire-Marcel C \& Péronnet $\mathrm{F}$ (2001) Oxidation of $\left({ }^{13} \mathrm{C}\right)$ glycerol ingested along with glucose during prolonged exercise. J Appl Physiol 90, 1685-1690.

Burelle Y, Péronnet F, Massicotte D, Brisson G \& Hillaire-Marcel C (1997) Oxidation of ${ }^{13} \mathrm{C}$-glucose and ${ }^{13} \mathrm{C}$-fructose ingested as a pre-exercise meal: effect of carbohydrate ingestion during exercise. Int J Sports Nutr 7, 117-127.

Chen M \& Whistler RL (1977) Metabolism of D-fructose. Adv Carb Chem Biochem 34, 285-343.

Couture S, Massicotte D, Lavoie C, Hillaire-Marcel C \& Péronnet F (2002) Oral ${ }^{13} \mathrm{C}$-glucose and endogenous energy substrate oxidation during prolonged treadmill running. J Appl Physiol 92, $1255-1260$.

Craig H (1953) The geochemistry of stable isotopes. Geochem Cosmochem Acta 3, 53-92.

Décombaz J, Sartori D, Arnaud MJ, Thélin AL, Schürch P \& Howald H (1985) Oxidation and metabolic effects of fructose and glucose ingested before exercise. Int J Sports 6, 282-286.

Ferraris RP \& Diamond J (1997) Regulation of intestinal sugar transport. Physiol Rev 77, 257-302.

Ganda OP, Soldner JS, Gleason RE \& Cleator IGM (1979) Metabolic effect of glucose, mannose, galactose, and fructose in man. $J$ Clin Endocrinol Metab 49, 616-622.

Guézennec CY, Satabin P, Duforez F, Merino D, Péronnet F \& Koziet J (1989) Oxidation of corn starch, glucose, and fructose ingested before exercise. Med Sci Sports Exerc 21, 45-50.

Jandrain BJ, Pallikarakis N, Normand S, et al. (1993) Fructose utilization during exercise in men: rapid conversion of ingested fructose to circulating glucose. $J$ Appl Physiol 74, 2146-2154.

Jentjens RLP, Achten J \& Jeukendrup AE (2004a) High oxidation rates from combined carbohydrates ingested during exercise. Med Sci Sports Exerc 36, 1551-1558.

Jentjens RLP, Venables MC \& Jeukendrup AE (2004b) Oxidation of exogenous glucose, sucrose, and maltose during prolonged cycling exercise. J Appl Physiol 96, 1285-1291.

Jeukendrup AE (2004) Carbohydrate intake during exercise and performance. Nutrition 20, 669-677.

Jeukendrup AE, Wagenmakers AJM, Stegen JHCH, Gijsen AP, Brouns F \& Saris WHM (1999) Carbohydrate ingestion can completely suppress endogenous glucose production during exercise. Am J Physiol 276, E672-E683.

Kellett GL (2001) The facilitated component of intestinal glucose absorption. Topical review. J Physiol 531, 585-595.

Lefèbvre PJ (1985) From plant physiology to human metabolic investigations. Diabetologia 28, 255-263.

Leijssen DPC, Saris WHM, Jeukendrup AE \& Wagenmakers AJM (1995) Oxidation of exogenous $\left[{ }^{13} \mathrm{C}\right]$ galactose and $\left[{ }^{13} \mathrm{C}\right]$ glucose during exercise. J Appl Physiol 79, 720-725.

Massicotte D, Péronnet F, Adopo E, Brisson GR \& Hillaire-Marcel C (1994) Effect of metabolic rate on the oxidation of ingested glucose and fructose during exercise. Int $J$ Sports Med $\mathbf{1 5}$, $177-180$.

Massicotte D, Péronnet F, Allah C, Hillaire-Marcel C, Ledoux M \& Brisson G (1986) Metabolic response to $\left[{ }^{13} \mathrm{C}\right]$ glucose and $\left[{ }^{13} \mathrm{C}\right]$ fructose ingestion during exercise. J Appl Physiol 61, 1180-1184.

Massicotte D, Péronnet F, Brisson G, Bakkouch K \& Hillaire-Marcel C (1989) Oxidation of a glucose polymer during exercise: comparison with glucose and fructose. J Appl Physiol 66, 179-183.

Massicotte D, Péronnet F, Brisson G, Boivin L \& Hillaire-Marcel C (1990) Oxidation of exogenous carbohydrate during prolonged exercise in fed and fasted conditions. Int J Sports Med $\mathbf{1 1}$ $253-258$.

Pallikarakis N, Sphiris N \& Lefèbvre P (1991) Influence of the bicarbonate pool on the occurrence of ${ }^{13} \mathrm{CO}_{2}$ in exhaled air. Eur J Appl Physiol 63, 179-183.

Pereira LO \& Lancha AH (2004) Effect of insulin and contraction up on glucose transport in skeletal muscle. Review. Prog Biophys Mol Biol 84, 1-27.

Péronnet F \& Massicotte D (1991) Table of non protein respiratory quotient: an update. Can J Sport Sci 16, 23-29.

Pirnay F, Sheen AJ, Gautier JF, Lacroix M, Mosora F \& Lefébvre PJ (1995) Exogenous glucose oxidation during exercise in relation to the power output. Int J Sports Med 16, 456-460.

Ruzzin J, Péronnet F, Tremblay J, Massicotte D \& Lavoie C (2003) Breath $\left[{ }^{13} \mathrm{CO}_{2}\right]$ recovery from an oral glucose load during exercise: comparison between $\left[\mathrm{U}-{ }^{13} \mathrm{C}\right]$ and $\left[1,2-{ }^{13} \mathrm{C}\right]$ glucose. $J$ Appl Physiol 95, 477-482.

Santer R, Hillebrand G, Steinmann B \& Schaub J (2003) Intestinal glucose transporter: evidence for a membrane traffic-base pathway in humans. Gastroenterology 124, 34-39.

Slama G, Boillot J, Hellal I, Darmaun D, Rizkalla SW, Orvoen-Friza E, Doré MF, Guille G, Fretault J \& Coursaget J (1989) Fructose is as good a fuel as glucose for exercise in normal subjects. Diabet Metabol (Paris) 15, 105-106.

Stellaard F, Koetse HA, Elzinga H, Boverhof R, Tjoonk R, Klimp A, Vegter D, Liesker J \& Vonk RJ (2000) ${ }^{13} \mathrm{C}$-carbohydrate breath test: impact of physical activity on the rate-limiting step in lactose utilization. Scand J Gastroenterol 35, 819-823.

Stümpel F, Burcelin R, Jungermann K \& Thorens B (2001) Normal kinetics of intestinal glucose absorption in the absence of GLUT2: evidence for a glucose pathway requiring glucose phosphorylation and transfer into the endoplasmic Reticul. Proc Nat Acad Sci (USA) 98, 11330-11335.

Trimmer JK, Casazza GA, Horning MA \& Brooks GA (2001) Recovery of ${ }^{13} \mathrm{CO}_{2}$ during rest and exercise after $\left[1-{ }^{13} \mathrm{C}\right]$ acetate, $\left[2-{ }^{13} \mathrm{C}\right]$ acetate, and $\mathrm{NaH}^{13} \mathrm{CO}_{3}$ infusions. Am $J$ Physiol 281, E683-E692.

Wagenmakers AJM, Brouns F \& Saris WHM (1993) Oxidation rate of orally ingested carbohydrates during prolonged exercise in man. J Appl Physiol 75, 2774-2780.

Wallis GA, Rowlands DS, Shaw C, Jentjens RL \& Jeukendrup AE (2005) Oxidation of combined ingestion of maltodextrins and fructose during exercise. Med Sci Sports Exerc 37, 426-432.

Williams CA (1986) Metabolism of lactose and galactose in man. Prog Biochem Pharmacol 21, 219-247.

Wright EM, Martin GM \& Turk E (2003) Intestinal absorption in health and disease - sugars. Best Pract Res Clin Gastroenterol 17, 943-956. 